\title{
228. ポリアクリルアミドを用いたPET用ファントム
}

\section{Acrylamide Polymer Gel Phantom for PET}

名古屋市総合リハビリテーションセンター

○百石 悟 - 满島 岳珠 - 荒木 克已. 伴野 辰雄 - 加藤 統之

(Hyakkoku Satoru) (Mitsushima Takejyu) (Araki Katsumi) (Banno Tatsuo) (Kato Noriyuki)

住友重機加速器サービス 川角 保広

(Kawasumi Yasuhiro)

Iホホリアクリルアミドを材料として用い、頭部臨床モデルPET用ファントムを作成

11.上記ファァンムをPET装置にて測定し検討

使用機器 PET装置：PCT3600W (旦立) サイクロトロン: CYPRIS-370 (住龙重機)

PET画像収集条件：7スライス静止モード30分収集，スライス厚 $12 \mathrm{~mm}$; 分解能 $10 \mathrm{~mm}$ (半值幅)

（1）ポリアクリルアミドゲル（含RI）作製

1. Tris-Aminomethane $0.08 \mathrm{M}$, EDTA(2Na) 2mMの水溶液を緩衝液として用い、Acrylamide $95 \%$ \&

$\mathrm{N}, \mathrm{N}$ methylene bisacrylamide $5 \%$ 混合物の $5 \%$ 溶液を作る。

2.この溶液に ${ }^{18} \mathrm{FDG}$ 入れ任意のRI濃度とする。

3. 重合剤としてAmmonium Peroxosulfate 0.1\%, TEMED 0.2\%を入れると約 15 分でゲル状に固まる。

(2) ポリアクリルアミドゲル頭部臨床モデルPET用ファントム図

今回作製した頭部モデルファントムを図1に示す。外枠はCross Calibration用円筒形ファントム（内径

$14 \mathrm{~cm} \phi)$ である。灰白質部分 $(G)$ ，白質部分 (W)、脳室部分 $(V)$ 、梗塞部位を想定した低RI濃度

領域（A,B,C）を上記方法にて固めた。表1はそのRI濃度を示す。

灰白質部分の $6000 \mathrm{cps} / \mathrm{g}$ はCO2Gas 臨床PET検査の血中RI濃度を参考にした。

A,B,Cは 灰白質、白質の $30 \%$ の RI濃度（Cは除く）及び0cps/gとし た。

また、直径 $5,8,13,15,20 \mathrm{~mm}$ の場合 について作製し、それぞれについて PET装置にて測定した。

表1 \begin{tabular}{|c|c|c|}
\hline & \multicolumn{2}{|c|}{ RI濃度 (cps/g) } \\
\hline G & \multicolumn{2}{|c|}{6000} \\
\hline W & \multicolumn{2}{|c|}{2400} \\
\hline V & \multicolumn{2}{|c|}{0} \\
\hline A & 1800 & 0 \\
\hline B & 720 & 0 \\
\hline C & & 0 \\
\hline
\end{tabular}

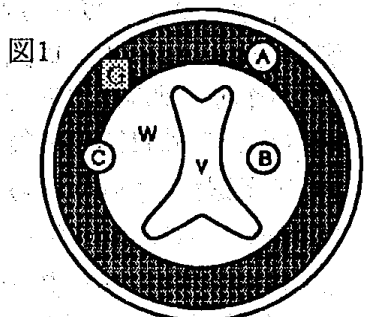

(3) 低いRl濃度領域が周辺領域から受ける影響をあらわすグラン

ファントム画像から A,B,C領域の平均PET值を測定し、RI濃度に換算したグラフを示す。

横軸：A,B,Cの直径(mm)

縦軸 $\therefore \mathrm{A}, \mathrm{B}, \mathrm{C}$ 領域のPET值から換算したRI濃度の周辺領域のRI濃度に対する\%

(A領域の場合 $6000 \mathrm{cps} / \mathrm{g} 、 \mathrm{~B}$ 領域の場合 $2400 \mathrm{cps} / \mathrm{g} 、 C$ 領域の場合 $6000 \mathrm{cps} / \mathrm{g}$ を $100 \%$ とする)
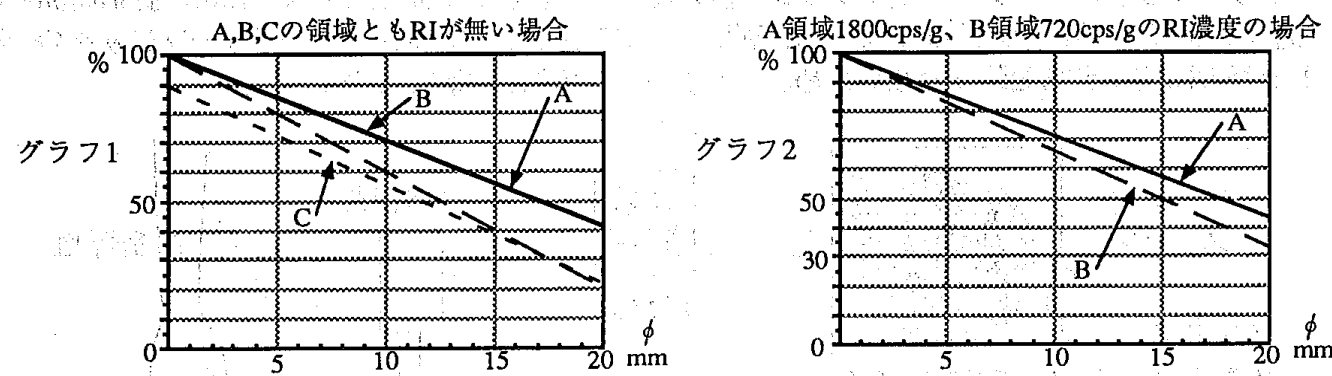

低RI濃度領域の径が小さいほどPET值が高く表示されるため本来示すべきRI濃度（グラフ1の場 合0\%、グラフ2の場合30\%）より高い\%のグラフとなる。

【まとめ】

(1) PET用ポリアクリルアミドゲルファントムの特徵

a. 任意のRI濃度領域が簡便に作製可能

b. 隔壁のない任意の形が簡便に作製可能

（2）低いRI濃度領域が周辺領域から受ける影響

低いRI濃度領域が20mm ф以下の場合、実際のRI濃度のPET值よりも高い值を表示している。これは、 臨床時に抢いて定量值が高めに測定されている可能性があることを示唆しているように思われる。 